\title{
Australian Journal of \\ Crop Science \\ Effect of resistance elicitors on the biology and feeding preference of Spodoptera frugiperda (J.E.Smith) (Lepidoptera: Noctuidae) in corn
}

\author{
Janaina Marques Mondego ${ }^{1}$, Keneson Klay Gonçalves Machado ${ }^{1}$, Leonardo de Jesus Machado Gois de \\ Oliveira ${ }^{1}$, Raimunda Nonata Santos de Lemos ${ }^{* 1}$, Jacinto de Luna Bastista ${ }^{2}$, Altamiro Souza de Lima Ferraz \\ Junior ${ }^{1}$, Ana Maria Silva de Araujo ${ }^{1}$, Paulo Alexandre Fernandes Rodrigues de Melo ${ }^{1}$, Mario Luiz Ribeiro \\ Mesquita $^{3}$
}

${ }^{1}$ Universidade Estadual do Maranhão, Centro de Ciências Agrárias, Programa de Pós-Graduação em Agroecologia, CP 65.055-098, São Luís, MA, Brasil

${ }^{2}$ Universidade Federal da Paraíba/ Campus Areia, Centro de Ciências Agrárias, Programa de Pós-Graduação em Agronomia, Brasil

${ }^{3}$ Universidade Estadual do Maranhão, Programa de Pós-Graduação em Agricultura e Ambiente, Brasil

\section{*Corresponding author: rlemos@cca.uema.br}

\begin{abstract}
This study searches for efficient and low environmental impact alternatives to control Spodoptera frugiperda. Application of elicitors capable of inducing resistance in plants has already been highlighted. The elicitors trigger the plant's defense capacity against attack of herbivores and phytopathogenic organisms. Thus, the present study aimed to evaluate the effect of resistance elicitors on some biological aspects and food preference of Spodoptera frugiperda (J. E. Smith) in corn in laboratory conditions. The treatments consisted of: Control (distilled water); Biofertilizer ( $\left.25 \mathrm{~mL} \mathrm{~L}^{-1}\right)$; Acibenzolar-S-methyl-ASM ( $\left.2 \mathrm{mg} \mathrm{mL}^{-1}\right)$; Potassium silicate $\left(10 \mathrm{~mL} \mathrm{~L}^{-1}\right)$ and T5: Potassium silicate $\left(10 \mathrm{~mL} \mathrm{~L}^{-1}\right)+$ ASM $\left(2 \mathrm{mg} \mathrm{mL}^{-1}\right)$. The treatments were foliar application of elicitors with adjustable jet pressure sprayer to the whole plant with an amount of $20 \mathrm{~mL}$ of the solution per plant. The larval phase (weight at 7 and 14 days, duration and viability); pupal phase (weight after $24 \mathrm{~h}$, duration and viability) and adult phase (number of eggs / female, number of eggs/posture/female and longevity of adults) were evaluated. Free-choice and no-choice food preference test experiments were also carried out on 1st and 3rd instar caterpillars, after which the leaves collected at 5 and 10 days after spraying. The results showed that Acibenzolar-S-methyl induces resistance in corn plants when applied either alone or together with potassium silicate. Therefore, it adversely affects development of $S$. frugiperda. The leaves treated with Potassium Silicate + ASM were less preferred and consumed by 1st and 3rd instar caterpillars in free-choice food preference test.
\end{abstract}

Keywords: Acibenzolar-S-Methy; Fall Armyworm; Potassium Silicate.

Abbreviations: ASM_Acibenzolar-S-Methy; DAT_days after treatment application; DAE_days after emergence.

Introduction

Food production is constantly threatened by the insect pest attack. In the corn crop, the entomofauna is quite diverse. The caterpillar Spodoptera frugiperda (J.E. Smith, 1797) is a key pest in corn. It is a polyphagous insect that, besides feeding on corn, has preference for other grasses such as wheat (Triticum aestivum L.), sorghum (Sorghum bicolor L.), rice (Oryza sativa L.), cotton (Gossypium hirsutum L.) and beans (Phaseolus vulgaris L.) (Boregas et al., 2013).

The control of $S$. frugiperda is usually carried out with chemical insecticides. In most cases, the applications are performed late in the cropping season, when the insect population is above the control level. Thus these applications are not always efficient and can cause several problems to human and the environment. The damage magnitude caused by $S$. frugiperda has induced the development of alternative methods such as the use of biological control (Thomazoni et al., 2014), resistant plants (Toscano et al., 2016), plants with insecticidal action (Almeida et al., 2017) and resistance elicitors (War et al., 2015).

The induction of resistance is a viable alternative, being a management practice that can be done with applications of abiotic inducers. The induced defense in plants consists in the formation of mechanical barriers and/or alteration of the biochemical responses of the plant to the attack of herbivores, increasing the synthesis of proteins, which would act as toxins or as switches of the pest metabolism (Stangarlin et al., 2011).

In the literature, there are papers that seek to investigate the use of products that promote plant resistance, which interferes with the biology of pest insects, as well as their dietary habits. Previous studies have shown that the 
application of silicon to corn (Zea mays L.) and sunflower (Helianthus annuus L.) plants has reduced the number of Chlosyne lacinia saundersii (Doubleday and Hewitson, 1849) (Lepidoptera: Nymphalidae) in $\mathrm{H}$. annuus. The application of silicon does not directly affect the infestation of $S$. frugiperda but favors the occurrence of the predator Dorus spp. (Antunes et al., 2010).

Application of silicon and acibenzolar-S-methyl (ASM) in wheat plants reduced the number of nymphs, extending the duration of the pre-reproductive period and the number of honeydew drops of the green aphid Schizaphis graminum (Rondani, 1958) (Pereira et al., 2010).

Considering the high expenses of controlling S. frugiperda, the use of elicitors capable of promoting the induction of resistance is a promising alternative, since induction of resistance allows to reduce the pest population density below the economic damage level, with minimum impact on the environment, being compatible with other control methods. In this context, the present study aimed to evaluate the effect of resistance elicitors on some biological aspects and food preference of $S$. frugiperda on corn. The results of this work can provide indication of promising resistance elicitors to be used in integrated pest management of S. frugiperda.

\section{Results and Discussion}

\section{Biological aspects of S. frugiperda}

Significant differences between treatments were observed throughout the whole larval phase (Table 1). Acibenzolar-Smethyl (ASM) treatment showed the lowest weight at seven days. The same result was observed at 14 days along with potassium silicate + ASM, which differed from the control. The larval viability was negatively affected by ASM (68\%) and potassium silicate + ASM (64\%) treatments, which were statistically similar to each other. In general, ASM-fed caterpillars had the shortest duration in the larval period (17.40 days) and an extension of this phase was observed when they were fed with potassium silicate + ASM (20.18 days) (Table 1 ).

The results of this research corroborate with Massey et al. (2009) who verified a reduction in the weight of Spodoptera exempta caterpillars (Walker, 1856), fed with different diets containing silicon.

In the present study, the lower weight and viability of $S$. frugiperda caterpillars in the treatments with ASM and its combination, with potassium silicate may be the result of increased leaf tissue stiffness due to accumulation and polymerization of silicate compounds on plant cell walls (Keeping et al., 2009; Datnoff et al., 2001), hindering penetration and chewing of these tissues by insects and decreasing the leaf digestibility (Goussain et al., 2002; Körndorfer et al., 2011), consequently interfering negatively in the development of these insects.

The larval period extension observed in the treatment of potassium silicate + ASM may be related to a food substrate nutritional inadequacy that probably extended the larval period. This type of response is desirable in integrated pest management programs, since the increase of the larval stage may favor action of natural enemies. Therefore, the caterpillars will be exposed for a longer time. In addition, they will complete fewer generations per corn phenological cycle.

Corn leaves treated with ASM and potassium silicate + ASM provided the lowest weight gain in male and female pupae, which significantly differed from the control (Table 2). However, there was no difference between the treatments for pupae viability. On the other hand, diferences were observed in the pupal period duration, where the treatment potassium silicate + ASM presented the longest duration (10.46 days) compared to the control and biofertilizer treatments (Table 2).

The efficiency of foliar applied ASM and potassium silicate + ASM in S. frugiperda in the present study probably occurred due to their anti-nutritive effects observed in the larval stage, which directly influenced the pupae weight. The pupae lower weight may promote changes in insect fertility resulting in small moths and non-viable eggs (Rodriguez and Vendramim, 1996). This is a positive factor, since it will possibly allow a reduction of this pest and damage to the crop, besides reducing the costs of pesticide applications.

The combination of potassium silicate + ASM provided fewer eggs / female differing from the control (Table 3). However, for the eggs / oviposition / female parameter there was no difference and the values varied between 170.45 (biofertilizer) and 133.61 (potassium silicate + ASM). The longevity of $S$. frugiperda adults was similar between treatments and varied from 12.26 (potassium silicate) to 9.21 days (potassium silicate + ASM).

The insect fertility is a biological parameter, in which the silicon effect is most observed. In the present study, the observed decrease in fertility indicates a negative influence of the potassium silicate + ASM, which can result in a lower insect population density, and consequently, lower potential for plant damage. These results corroborate with studies conducted by Nascimento et al. (2018), which showed reduced viability and numbers of eggs of $S$ frugiperda females fed with silicon treated plants applied both by leaf and soil. Silva et al. (2014) observed that the application of silicon in cotton promoted a reduction in the production of eggs / female of $S$. frugiperda.

ASM acts as an activator of the plant's natural defenses against pests and diseases (Tomquelski et al., 2007). In the present study, some biological aspects of $S$. frugiperda were affected by this compound when applied alone or in combination with potassium silicate. This may be associated to a possible induction of the synthesis of defense substances causing negative effect on this insect pest. Costa et al. (2011) assessed the effect of silicon and acibenzolar-Smetyl on the induction of green aphid ( $S$. graminum) resistance in wheat and found a reduction in the number of adults and nymphs in the treatments that received the combination of silicon + ASM and ASM alone, constituting 
Table 1. Weight at 7 and 14 days, viability and larval period (days) of Spodoptera frugiperda fed with corn leaves treated with different resistance elicitors.

\begin{tabular}{|c|c|c|c|c|}
\hline \multirow[t]{2}{*}{ Treatments } & \multicolumn{2}{|l|}{ Weight $(\mathrm{mg})^{1,3}$} & \multirow{2}{*}{$\begin{array}{l}\text { Viability (\%) } \\
(n=50)^{1,3}\end{array}$} & \multirow{2}{*}{$\begin{array}{l}\text { Larval }^{2} \\
\text { Period }\end{array}$} \\
\hline & $\begin{array}{l}7 \text { days } \\
(n=50)\end{array}$ & $\begin{array}{l}14 \text { days } \\
(n=50)\end{array}$ & & \\
\hline Control & $38.71 \pm 3.36 a$ & $308.20 \pm 17.05 a$ & $92.0 \pm 3.87 a$ & $\begin{array}{l}18.33 \pm 0.16 b \\
(n=46)\end{array}$ \\
\hline Acibenzolar-S-metil - ASM & $16.84 \pm 2.41 \mathrm{c}$ & $202.84 \pm 18.30 b$ & $68.0 \pm 6.66 b$ & $\begin{array}{l}17.40 \pm 0.17 c \\
(n=34)\end{array}$ \\
\hline Biofertilizer & $26.11 \pm 3.14 b$ & $220.80 \pm 25.0 \mathrm{ab}$ & $80.0 \pm 5.71 a b$ & $\begin{array}{l}18.56 \pm 0.24 b \\
(n=40)\end{array}$ \\
\hline Potassium silicate & $22.35 \pm 2.96 b c$ & $252.72 \pm 21.38 a b$ & $74.0 \pm 6.26 a b$ & $\begin{array}{l}18.42 \pm 0.21 b \\
(n=37)\end{array}$ \\
\hline Potassium silicate + ASM & $17.41 \pm 2.44 \mathrm{bc}$ & $200.16 \pm 21.05 b$ & $64.0 \pm 6.85 b$ & $\begin{array}{l}20.18 \pm 0.21 a \\
(n=32)\end{array}$ \\
\hline C.V. (\%) & 12.34 & 10.59 & 19.17 & -- \\
\hline
\end{tabular}

${ }^{1}$ Means ( \pm EP) followed by the same vertical letter do not differ statistically from each other by the Tukey test at the $5 \%$ probability level; ${ }^{2}$ Means ( \pm $\mathrm{SE}$ ) followed by the same letter vertically do not differ statistically from each other by the Kruskal-Wallis test at the $5 \%$ probability level; ${ }^{3}$ Data transformed into $\sqrt{x}$. Values in parentheses express the number of replicates per treatment.

Table 2. Weight (after $24 \mathrm{~h}$ ), viability and pupal period of Spodoptera frugiperda fed with corn leaves treated with different resistance elicitors.

\begin{tabular}{|c|c|c|c|c|}
\hline \multirow[t]{2}{*}{ Treatments } & \multicolumn{2}{|l|}{ Pupal weight ${ }^{1,3}$} & \multirow[t]{2}{*}{ Pupal viability $^{2}(\%)$} & \multirow{2}{*}{$\begin{array}{l}\text { Pupal Period }{ }^{2} \\
\text { (Days) }\end{array}$} \\
\hline & Male $(X \pm E P)$ & Female $(\mathrm{X} \pm \mathrm{EP})$ & & \\
\hline Control & $\begin{array}{c}198.10 \pm 5.74 a \\
(n=24)\end{array}$ & $\begin{array}{c}189 \pm 4.75 a \\
(n=22)\end{array}$ & $\begin{array}{l}93.48 \pm 3.68 a \\
(n=46)\end{array}$ & $\begin{array}{c}9.34 \pm 0.20 b \\
(n=43)\end{array}$ \\
\hline $\begin{array}{l}\text { Acibenzolar-S-methyl - } \\
\text { ASM }\end{array}$ & $\begin{array}{c}170.45 \pm 5.23 b \\
\quad(n=16)\end{array}$ & $\begin{array}{c}174.80 \pm 5.96 a b \\
(n=29)\end{array}$ & $\begin{array}{c}100.00 \pm 0.00 a \\
(n=34)\end{array}$ & $\begin{array}{c}9.64 \pm 0.24 a b \\
(n=34)\end{array}$ \\
\hline Biofertilizer & $\begin{array}{c}195.18 \pm 8.68 a b \\
(n=18)\end{array}$ & $\begin{array}{c}166.00 \pm 5.73 a b \\
(n=22)\end{array}$ & $\begin{array}{c}100.00 \pm 0.00 a \\
\quad(n=34)\end{array}$ & $\begin{array}{c}9.12 \pm 0.17 b \\
(n=24)\end{array}$ \\
\hline Potassium silicate & $\begin{array}{c}180.50 \pm 5.55 a b \\
(n=16)\end{array}$ & $\begin{array}{c}178.70 \pm 5.80 a b \\
(n=21)\end{array}$ & $\begin{array}{l}92.5 \pm 4.22 a \\
\quad(n=37)\end{array}$ & $\begin{array}{c}9.75 \pm 0.20 a b \\
(n=27)\end{array}$ \\
\hline Potassium silicate + ASM & $\begin{array}{c}177.31 \pm 3.53 a b \\
(n=14)\end{array}$ & $\begin{array}{c}163.97 \pm 8.63 b \\
(n=18)\end{array}$ & $\begin{array}{c}90.32 \pm 5.40 a \\
(n=31)\end{array}$ & $\begin{array}{c}10.46 \pm 0.24 a \\
(n=28)\end{array}$ \\
\hline C.V. (\%) & 13.10 & 15.02 & --- & --- \\
\hline
\end{tabular}

${ }^{1}$ Means followed by the same letter vertically do not differ statistically from each other by the Tukey test at the $5 \%$ probability level; ${ }^{2}$ Means followed by the same vertical letter do not differ statistically from each other by the Kruskal-Wallis test at the $5 \%$ probability level; ${ }^{3}$ Data transformed into $\sqrt{x}$. Values in parenthesis express the number of the treatment replications.

Table 3. Fertility and longevity of adults (days) of Spodoptera frugiperda fed with corn leaves treated with different resistance elicitors.

\begin{tabular}{llll}
\hline Treatments & Eggs/female $^{1,2}$ & $\begin{array}{l}\text { Eggs/oviposition/ } \\
\text { female }^{1,2}\end{array}$ & Adult longevity $^{3}$ \\
\hline Control & $972.70 \pm 76.73 \mathrm{a}$ & $178.70 \pm 15.22 \mathrm{a}$ & $11.88 \pm 0.72 \mathrm{a}$ \\
Acibenzolar-S-methyl - ASM & $841.47 \pm 71.93 \mathrm{ab}$ & $141.91 \pm 11.84 \mathrm{a}$ & $10.58 \pm 0.47 \mathrm{a}$ \\
Biofertilizer & $869.09 \pm 123.88 \mathrm{ab}$ & $170.45 \pm 28.49 \mathrm{a}$ & $11.18 \pm 1.19 \mathrm{a}$ \\
Potassium silicate & $845.21 \pm 61.17 \mathrm{ab}$ & $165.89 \pm 14.00 \mathrm{a}$ & $12.26 \pm 0.70 \mathrm{a}$ \\
Potassium silicate + ASM & $638.28 \pm 767.71 \mathrm{~b}$ & $133.61 \pm 17.71 \mathrm{a}$ & $9.21 \pm 0.85 \mathrm{a}$ \\
\hline
\end{tabular}

\begin{tabular}{lccc}
\hline C.V. (\%) & 21.96 & 23.72 & ---- \\
${ }^{1}$ Means followed by the same letter vertically do not differ statistically from each other by the Tukey test at the 5\% probability level; ${ }^{2}$ Data
\end{tabular}

converted to $\sqrt{x}$; ${ }^{3}$ Means followed by the same vertical letter do not differ statistically from each other by the Kruskal-Wallis test at the $5 \%$ probability level. 
Table 4. Average number and leaf consumption of 1st instar caterpillars of Spodoptera frugiperda, fed with corn leaves in freechoice feeding preference test performed at 5 and 10 days after product application.

\begin{tabular}{|c|c|c|c|c|c|c|}
\hline \multirow{3}{*}{ Treatments } & \multicolumn{6}{|c|}{5 days after application } \\
\hline & \multicolumn{5}{|c|}{ Average number of caterpillars ${ }^{1}$} & \multirow{2}{*}{$\begin{array}{l}\text { Leaf } \\
\text { consumption } \\
\left(\mathrm{cm}^{2}\right)\end{array}$} \\
\hline & $2 \mathrm{~h}$ & $4 \mathrm{~h}$ & $6 \mathrm{~h}$ & $12 \mathrm{~h}$ & $24 \mathrm{~h}$ & \\
\hline Control & $4.10 \mathrm{a}$ & $4.30 \mathrm{a}$ & $4.80 \mathrm{a}$ & $4.60 \mathrm{a}$ & $4.70 \mathrm{a}$ & $0.41 \mathrm{a}$ \\
\hline Acibenzolar-S-methyl-ASM & $2.60 \mathrm{a}$ & $2.20 \mathrm{a}$ & $2.10 \mathrm{a}$ & $2.10 \mathrm{a}$ & $1.90 \mathrm{~b}$ & $0.24 \mathrm{~b}$ \\
\hline Biofertilizer & $2.50 \mathrm{a}$ & $3.00 \mathrm{a}$ & $3.20 \mathrm{a}$ & $2.70 \mathrm{a}$ & $2.80 \mathrm{~b}$ & $0.27 \mathrm{~b}$ \\
\hline Potassium silicate & $3.30 \mathrm{a}$ & $3.20 \mathrm{a}$ & $2.50 \mathrm{a}$ & $3.70 \mathrm{a}$ & $3.50 \mathrm{~b}$ & $0.23 \mathrm{~b}$ \\
\hline Potassijum silicate +ASM & $2.20 \mathrm{a}$ & $2.60 \mathrm{a}$ & $2.80 \mathrm{a}$ & $3.20 \mathrm{a}$ & $2.10 \mathrm{~b}$ & $0.23 b$ \\
\hline C.V. (\%) & - & - & - & - & - & 9.73 \\
\hline \multicolumn{7}{|l|}{10 days after application } \\
\hline Control & $4.80 \mathrm{a}$ & $4.90 \mathrm{a}$ & $5.90 \mathrm{a}$ & $5.20 \mathrm{a}$ & $5.40 \mathrm{a}$ & $0.44 a$ \\
\hline Acibenzolar-S-methyl-ASM & $3.80 \mathrm{a}$ & $4.40 a b$ & $3.80 \mathrm{~b}$ & $3.70 \mathrm{~b}$ & $3.70 \mathrm{~b}$ & $0.26 a b$ \\
\hline Biofertilizer & $1.50 \mathrm{~b}$ & $1.80 \mathrm{c}$ & $2.60 \mathrm{bc}$ & $2.50 \mathrm{bc}$ & $2.60 \mathrm{bc}$ & $0.30 a b$ \\
\hline Potassium silicate & $1.60 \mathrm{~b}$ & $2.90 \mathrm{bc}$ & $3.00 \mathrm{bc}$ & $2.60 \mathrm{bc}$ & $2.60 \mathrm{bc}$ & $0.34 a b$ \\
\hline Potassium silicate +ASM & $1.60 \mathrm{~b}$ & $1.90 \mathrm{c}$ & $1.60 \mathrm{c}$ & $2.00 \mathrm{c}$ & $1.90 \mathrm{c}$ & $0.20 \mathrm{~b}$ \\
\hline C.V. (\%) & - & - & - & - & - & 10.27 \\
\hline
\end{tabular}

${ }^{1}$ Means followed by the same letter (column) do not differ statistically from each other by the Kruskal-Wallis test at the $5 \%$ level; ${ }^{2}$ Means followed by the same letter (column) do not differ statistically from each other by the Tukey test at the $5 \%$ level; ${ }^{3}$ For statistical analysis the data were transformed.$\sqrt{x+0,5}$

Table 5. Average number and leaf consumption of caterpillars of 3rd instar of Spodoptera frugiperda, fed with corn leaves in freechoice feeding preference test performed at 5 and 10 dias after products application.

\begin{tabular}{|c|c|c|c|c|c|c|}
\hline \multirow{3}{*}{ Treatments } & \multicolumn{5}{|c|}{5 days after application ${ }^{1}$} & \multirow{3}{*}{$\begin{array}{l}\text { Leaf consumption } \\
\left(\mathrm{cm}^{2}\right)\end{array}$} \\
\hline & \multicolumn{5}{|c|}{ Number of caterpillars } & \\
\hline & $2 \mathrm{~h}$ & $4 \mathrm{~h}$ & $6 \mathrm{~h}$ & $12 \mathrm{~h}$ & $24 \mathrm{~h}$ & \\
\hline Control & $5.20 \mathrm{a}$ & $4.30 \mathrm{a}$ & $4.50 \mathrm{a}$ & $4.70 \mathrm{a}$ & $5.00 \mathrm{a}$ & $1.13 \mathrm{a}$ \\
\hline Acibenzolar-S-methyl - ASM & $2.10 \mathrm{~b}$ & $2.40 \mathrm{~b}$ & $2.60 \mathrm{~b}$ & $2.60 \mathrm{~b}$ & $2.20 \mathrm{~b}$ & $0.64 \mathrm{~b}$ \\
\hline Biofertilizer & $2.60 \mathrm{~b}$ & $2.70 \mathrm{~b}$ & $2.70 \mathrm{~b}$ & $2.80 \mathrm{~b}$ & $2.90 \mathrm{~b}$ & $0.79 a b$ \\
\hline Potassium silicate & $2.30 \mathrm{~b}$ & $1.80 \mathrm{~b}$ & $1.90 \mathrm{~b}$ & $1.90 \mathrm{~b}$ & $1.80 \mathrm{~b}$ & $0.58 \mathrm{~b}$ \\
\hline Potassium silicate +ASM & $2.00 \mathrm{~b}$ & $1.80 \mathrm{~b}$ & $1.70 \mathrm{~b}$ & $2.20 \mathrm{~b}$ & $2.10 \mathrm{~b}$ & $0.63 \mathrm{~b}$ \\
\hline C.V. (\%) & - & - & - & - & - & 14.80 \\
\hline \multicolumn{7}{|l|}{10 days after application ${ }^{1}$} \\
\hline Control & $4.90 \mathrm{a}$ & $4.50 \mathrm{a}$ & $4.20 \mathrm{a}$ & $4.60 \mathrm{a}$ & $4.70 \mathrm{a}$ & $1.26 \mathrm{a}$ \\
\hline Acibenzolar-S-methyl - ASM & $2.30 \mathrm{bc}$ & $2.50 \mathrm{~b}$ & $2.70 a b$ & $2.80 \mathrm{~b}$ & $2.50 \mathrm{~b}$ & $0.71 \mathrm{ab}$ \\
\hline Biofertilizante & $3.40 a b$ & $3.20 a b$ & $3.20 a b$ & $3.00 \mathrm{~b}$ & $3.10 \mathrm{~b}$ & $0.68 a b$ \\
\hline Silicato de potássio & $2.00 \mathrm{c}$ & $2.60 \mathrm{~b}$ & $2.60 \mathrm{~b}$ & $2.50 \mathrm{~b}$ & $2.60 \mathrm{~b}$ & $0.67 a b$ \\
\hline Silicato de potássio +ASM & $0.90 \mathrm{~d}$ & $1.10 \mathrm{c}$ & $1.20 \mathrm{c}$ & $1.30 \mathrm{c}$ & $1.30 \mathrm{c}$ & $0.56 \mathrm{~b}$ \\
\hline C.V. (\%) & - & - & - & - & - & 12.98 \\
\hline
\end{tabular}

${ }^{1}$ Means followed by the same letter (column) do not differ statistically from each other by the Kruskal-Wallis test at the $5 \%$ level; ${ }^{2}$ Means followed by the same letter (column) do not differ statistically from each other by the Tukey test at the $5 \%$ level; ${ }^{3}$ For statistical analysis the data were transformed into $\sqrt{x+0,5}$.

these products in an alternative management tactic for this insect.

\section{Feeding preference test}

In the experiment conducted five days after treatment application (5 DAT) (Table 4), no significant difference among the treatments at 2, 4, 6 and $12 \mathrm{~h}$ were observed on 1 st instar caterpillars. The difference was only detected after $24 \mathrm{~h}$ in the untreated leaves (control) that were preferred and consumed by the caterpillars.

At 10 DAT (Table 4), a higher preference for feeding was observed in the leaves treated with ASM and control after 2 and $4 \mathrm{~h}$. The control treatment was also preferred for feeding at 6,12 and $24 \mathrm{~h}$, differing from the other treatments, while the less preferred leaves were those treated with potassium silicate + ASM, which did not differ from biofertilizer and potassium silicate treatmens. The lowest leaf consumption was verified in leaves treated with potassium silicate + ASM, differing significantly from the control (Table 4).

Biofertilizers, which are rich in microorganisms (bacteria, yeasts, filamentous fungi, actinomycetes and protozoans, among others) have great bioactive activity, triggering plant defense mechanisms, whose process occurs by stimuli or signals carried by the chemical mediators in the biofertilizer, 
Table 6. Average number and leaf consumption of caterpillars of 3rd instar of Spodoptera frugiperda $24 \mathrm{~h}$ after release, in corn leaves in no-choice feeding preference performed at 5 and 10 days after product application (DAT).

\begin{tabular}{|c|c|c|c|c|}
\hline \multirow[b]{3}{*}{ Treatments } & \multicolumn{4}{|l|}{ 1st Instar } \\
\hline & \multicolumn{2}{|l|}{5 DAT } & \multicolumn{2}{|l|}{10 DAT } \\
\hline & $\begin{array}{l}\text { Number of } \\
\text { caterpillars }\end{array}$ & $\begin{array}{l}\text { Leaf consumption } \\
\left(\mathrm{cm}^{2}\right)\end{array}$ & $\begin{array}{l}\text { Number of } \\
\text { caterpillars }\end{array}$ & $\begin{array}{l}\text { Leaf } \\
\text { consumption } \\
\left(\mathrm{cm}^{2}\right)\end{array}$ \\
\hline Control & $4.50 \mathrm{a}$ & $0.60 \mathrm{a}$ & $5.00 \mathrm{a}$ & $0.51 \mathrm{a}$ \\
\hline Acibenzolar-S-methyl - ASM & $4.50 \mathrm{a}$ & $0.41 \mathrm{a}$ & $4.70 \mathrm{a}$ & $0.44 \mathrm{a}$ \\
\hline Biofertilizer & $4.40 \mathrm{a}$ & $0.40 \mathrm{a}$ & $4.60 \mathrm{a}$ & $0.47 a$ \\
\hline Potassium silicate & $4.20 \mathrm{a}$ & $0.42 \mathrm{a}$ & $4.60 \mathrm{a}$ & $0.40 \mathrm{a}$ \\
\hline Potassium silicate +ASM & $3.90 \mathrm{a}$ & $0.33 \mathrm{a}$ & $4.90 \mathrm{a}$ & $0.39 \mathrm{a}$ \\
\hline \multirow[t]{2}{*}{ C.V. (\%) } & & 15.03 & & 12.28 \\
\hline & \multicolumn{3}{|c|}{ 3rd Instar } & \\
\hline Testemunha & $1.00 \mathrm{a}$ & $1.21 \mathrm{a}$ & $0.90 \mathrm{a}$ & $1.23 \mathrm{a}$ \\
\hline Acibenzolar-S-methyl - ASM & $0.80 \mathrm{a}$ & $0.63 a b$ & $0.80 \mathrm{a}$ & $0.66 \mathrm{~b}$ \\
\hline Biofertilizante & $0.90 \mathrm{a}$ & $0.79 a b$ & $0.90 \mathrm{a}$ & $0.67 \mathrm{~b}$ \\
\hline Silicato de potássio & $0.90 \mathrm{a}$ & $0.57 a b$ & $0.80 \mathrm{a}$ & $0.52 \mathrm{~b}$ \\
\hline Silicato de potassio +ASM & $0.70 \mathrm{a}$ & $0.45 b$ & $0.90 \mathrm{a}$ & $0.43 \mathrm{~b}$ \\
\hline C.V. (\%) & & 12.50 & & 14.25 \\
\hline
\end{tabular}

${ }^{1}$ Means followed by the same letter (column) do not differ statistically from each other by the Kruskal-Wallis test at the $5 \%$ level; ${ }^{2}$ Means followed by the same letter (column) do not differ statistically from each other by the Tukey test at the $5 \%$ level; ${ }^{3}$ For statistical analysis the data were transformed into $\sqrt{x+0,5}$.

producing defense reactions in the most distant tissues (Barbosa, 2007). The results obtained in the present research are in accordance with Alvarenga et al. (2017), which had the lowest food and consumption preference of $S$. frugiperda first instar caterpillars for corn leaves treated with silicon and gibberellic acid. Freitas et al. (2011) also observed that silicon interferes with food preference, consumption and mortality of Plutella xylostella (L.) caterpillars fed with cabbage leaves.

The silicon and acibenzolar-S-methyl activities were verified by Costa et al. (2007). They evaluated the effect of these products in the resistance induction to $S$. graminum green aphid in wheat and verified that the number of aphids in the control was nine times greater than in the plants that received application of silicic acid. In the free-choice test, leaf sections of plants treated with ASM and later with silicon (calcium silicate) and only with ASM were less colonized by green aphids.

We found that untreated corn leaves (control) were preferred by the 3 rd instar larvae at 5 DAT (Table 5) in all evaluation periods, differing significantly from the other treatments.

A less preference was observed for the leaves treated with potassium silicate + ASM at 10 DAT (Table 5), differing from the other treatments, while the higher food preference was verified in the control, which did not differ from the biofertilizer in the evaluations performed at 2 and $4 \mathrm{~h}$. In the evaluation performed at $6 \mathrm{~h}$ after release of the caterpillars, biofertilizer and ASM treatments did not differ significantly from the control. In the last evaluation periods, some caterpillars migrated from these treatments to the control that was preferred for feeding, differing from other treatments. Only the plants treated with potassium silicate + ASM differed from the control, presenting lower leaf consumption.

The efficiency of the potassium silicate and ASM products observed in this study is probably due to a possible presence of suppressive or deterrent substances to the insect that inhibited or reduced feeding. It may also be related to an increase in the production of plant compounds by activation of defense enzymes such as peroxidase, polyphenoloxidase and phenylalanine ammonia-lyase. In addition, changes in plant tissue can cause lignification, suberization and production of secondary metabolites and increased production of phytoalexins; thus, promoting plant defense against insects and pests (Gulsen et al., 2010).

Almeida et al. (2015) evaluated the effect of silicon sources application on attractiveness and preference of the Rhopalosiphum maidis aphid (Fitch, 1856) in two corn hybrids. They found existance of resistance elicitors has deterrence effects on corn hybrids (BM $207 \mathrm{C}$ and P30K64H $D$ ) in the tests of food preference with and without a choice, decreasing the aphid attractiveness in the leaves treated with calcium and magnesium silicate.

Comparing the results obtained in the experiments with a free-choice at 5 DAT, it was observed that all tested treatments (except for the control) were less preferred and less consumed by the 1st and 3rd instar caterpillars. However, a difference in attractiveness was observed for all treatments at 10 DAT, which resulted in a higher consumption, except for potassium silicate + ASM, evidencing a possible reduction of the effect of the treatments.

In the no-choice feeding preference test at 5 and 10 DAT with 1st and 3rd instar caterpillars, no differences between treatments were detected compared to food preference (Table 6).

With respect to consumption, no significant differences were observed at 5 and 10 DAT for 1st instar caterpillars, but significant differences were observed for the 3rd instar at 10 DAT between the control and the other treatments, and at 5 DAT between the control and potassium silicate + ASM.

The treatment combining potassium silicate and ASM was more efficient than the isolated treatments. This is probably 
due to the product combinations which provided some resistance to the leaves, with an increase in lignin and silicon content which was not determined during the evaluation. These results corroborate with the work conducted by Assis et al. (2015) who assessed the effects of silicon and acibenzolar-S-methyl on the resistance induction of sunflower plants to $C$. lacinia saundersii. The authors observed that the silicon application alone or combined with ASM favored the accumulation of this mineral and that ASM application provided lignin increase in sunflower plants.

Different modes of silicon application in rice plants (either drench or foliar) presented greater protection against $S$. frugiperda. The treated plants were five times less preferred for feeding when compared with the control leading to a reduction in the leaf consumption (Nascimento et al., 2014).

\section{Materials and Methods}

The research was carried out at the Entomology Laboratory of the Agronomy Biotechnology Nucleus of the Maranhão State University, Campus São Luis, Brazil, under controlled conditions of temperature $\left(25 \pm 2^{\circ} \mathrm{C}\right)$, relative humidity (70 $\pm 10 \%$ ) and photophase of $12 \mathrm{~h}$.

\section{Mass rearing of S. frugiperda}

For breeding, caterpillars were collected from corn fields in the city of São Luis, state of Maranhão, northeastern Brazil, separated and individualized in glass tubes $(8.5 \mathrm{~cm}$ in height $\times 2.5 \mathrm{~cm}$ in diameter) containing artificial diet (Grenne et al., 1976) and packed in climatic BOD type chamber with temperature $\left(25 \pm 1{ }^{\circ} \mathrm{C}\right)$, relative humidity $(70 \pm 10 \%)$ and photophase of $12 \mathrm{~h}$. The caterpillars remained in the glass tubes until the pupae stage, being sexed and placed in cages made of PVC tubes (10 cm in diameter $x 21 \mathrm{~cm}$ in height), closed at their ends by Petri dishes. The PVC tubes were coated on the inside with sulphite paper. The adults were fed a $10 \%$ honey solution. The ovipositions were placed in Petri dishes (10 cm in diameter) sealed with PVC plastic film until hatching of the caterpillars. After hatching, two caterpillars were inoculated into tubes containing the diet; thus, restarting the cycle.

\section{Plant material and treatments}

The plants used in the experiment were grown in greenhouse using four AG1051 maize seeds per pot with $6 \mathrm{~L}$ capacity. The substrate was composed of the soil fertilized according to soil analysis performed by the Soil Chemistry Laboratory of the Rural Engineering Technological Nucleus from Maranhão State University, Brazil. Ten days after emergence (DAE), corn plants were thinned, leaving the two more vigorous seedlings per pot. Soil moisture was maintained by means of daily irrigation.

The treatmens were foliar applied at 35 DAE (V6 stage). The treatments were: T1: Control (distilled water); T2: Biofertilizer (25 mL.L L $^{-1}$; T3: Acibenzolar-S-methyl-ASM (2 g.L' $\left.{ }^{1}\right)$, T4: Potassium silicate $\left(10 \mathrm{~mL} \cdot \mathrm{L}^{-1}\right)$; T5: Potassium silicate $\left(10 \mathrm{~mL} . \mathrm{L}^{-1}\right)+\operatorname{ASM}\left(2{\mathrm{~g} . \mathrm{L}^{-1}}^{-1}\right.$.

The biofertilizer was produced by anaerobic fermentation in a 500 L PVC box with the following constituents: cattle manure (50 kg), cow's milk (10 L), crushed sugar cane (2 kg), natural phosphate $(1 \mathrm{~kg})$ wood ash (1 kg) and boric acid (1 $\mathrm{kg})$. The solution was filled with water up to $500 \mathrm{~L}$ and had nitrogen sources ( $\mathrm{N}-\mathrm{NH} 4+$ and $\mathrm{N}-\mathrm{NO} 3-), \mathrm{N}_{\text {total }}$ (12.7), phosphorus $\left(18 \mathrm{~g} . \mathrm{kg}^{-1}\right)$, potassium $\left(1.5 \mathrm{~g} . \mathrm{kg}^{-1}\right)$ and $\mathrm{pH}$ of 6.6 . The treatment application was carried out via foliar using an adjustable spray jet pressure, applying to the whole plant with $20 \mathrm{~mL}$ of the solution per plant. Each plant base was protected with a polyethylene bag to avoid treatment deposition on the soil, avoiding product over-dosing. Fifty pots / treatments were used to study the biology and 10 pots / treatments for the food preference tests.

Corn leaves to be used in the bioassays were removed at five days after treatment application. This period corresponded to 40 days after emergence, at which time the crop is more susceptible to the fall armyworm attack (Cruz and Turpin, 1982). The collected leaves were taken to the laboratory, disinfected in water solution and sodium hypochlorite (10\%) for $5 \mathrm{~min}$, washed in running water and placed to dry on paper towel at room temperature.

\section{Biological aspects of S. frugiperda}

In this bioassay, the treated leaves were collected daily and taken to the laboratory to feed $S$. frugiperda. The experiment was carried out in a completely randomized design with five treatments and 50 replications per treatment. The experimental plot was composed of a plastic cup $(100 \mathrm{~mL}$ ) coated inside with filter paper moistened with distilled water to avoid leaf dryness, a piece of corn leaf ( 5 $\mathrm{cm}$ long) and a fresh-hatched larvae.

The caterpillar transfer to the cups was carried out with a sterilized soft bristles brush. The food was changed daily, according to each treatment until the caterpillars reach the pupa stage. After $24 \mathrm{~h}$, the pupae formed were collected, separated by sex, weighed on analytical balance and placed in PVC tubes $(10 \mathrm{~cm}$ in diameter $\times 21 \mathrm{~cm}$ in height), closed at their ends by Petri dishes. Adults emerged on the same date were grouped in pairs in a ratio of 1:1, remaining in PVC cages of the same dimensions already mentioned. The inside of the cages was coated with paper sheets to serve as a substrate for the ovipositions, which were collected daily, identified and stored in air-conditioned chambers for later counting of the eggs; thus, to avoid hatching of the caterpillars inside the cages.

The biology evaluations were performed $24 \mathrm{~h}$ after the experiment was begun. They were: Larval phase (weight at 7 and 14 days, duration and viability); Pupal stage (weight after $24 \mathrm{~h}$, duration and viability) and Adult phase (number of eggs / female, number of eggs / oviposition / female and longevity of adults).

\section{Food preference test}

For the S. frugiperda free-choice and no-choice food preferencece tests two experiments were carried out. The first at 5 and and the second at 10 days after treatment. Applications were made with 1st and 3rd instar caterpillars. In the free-choice food preference test, in trials with first instar caterpillars, leaves cut with a $3 \mathrm{~cm}^{2}$ punch were used and arranged equidistantly in Petri dishes $(19 \mathrm{~cm}$ in diameter). In the 3 rd instar caterpillar test, $5 \mathrm{~cm}^{2}$ leaves were used, placed in boxes $31 \times 31 \times 3.5 \mathrm{~cm}$ and arranged in 
the same condition already described. In both experiments, 20 S. frugiperda caterpillars were released and the containers were sealed with PVC plastic film.

The experiment was laid out in randomized complete block design with five treatments and 10 replications. The food preference was evaluated by counting the number of caterpillars present in each treatment after 2, 4, 6, 12 and 24 $\mathrm{h}$ of the release. Foliar consumption was determined $24 \mathrm{~h}$ after insect release. It was calculated by the difference between the leaf area, before being supplied to the caterpillars, and leaf area remaining after the end of the experiment. The leaf sections were oven dried at $60{ }^{\circ} \mathrm{C}$ for one day and weighed on analytical balance.

The non-choice food preference test was conducted with 1st and 3rd instar larvae in two experiments both laid out in randomized complete design with five treatments and ten replications. Each experiment was composed of Petri dishes (8 $\mathrm{cm}$ in diameter) coated with filter paper moistened with distilled water, where a leaf disc was deposited with the dimensions already described, with the release of five first instar caterpillars. The same procedure was performed for 3 rd instar caterpillars. However, only one caterpillar was released. In both experiments the plates were sealed with PVC film. After $24 \mathrm{~h}$, the number of caterpillars in each treatment was assessed and foliar consumption was measured as described in the free-choice feeding preference test.

\section{Statistical analysis}

Data on the larval and pupal periods, pupal viability, adult longevity and food preference were compared by KruskalWallis non-parametric test. The other biological parameters and leaf consumption were transformed into $\sqrt{x}$ and $\sqrt{x+0,5}$, respectively in order to perform the Analysis of Variance by the $\mathrm{F}$ test. The means were compared by the Tukey test at $5 \%$ significance. Statistical analysis was performed using the software Assistat, version 7.7 (Silva and Azevedo, 2016).

\section{Conclusion}

Acibenzolar-S-methyl (ASM) when applied alone or combined with potassium silicate induces resistance in corn plants adversely affecting $S$. frugiperda development. Leaves treated with potassium silicate + ASM were less preferred and consumed by 1 st and 3rd instar caterpillars in a freechoice feeding preference test. The potassium silicate + ASM treatment showed residual effect up to 10 days after application for caterpillars of 1st instar in the free-choice feeding preference test and of the 3rd instar in the nochoice feeding preference test.

\section{Aknowledgements}

To Fundação de Amparo à Pesquisa e ao Desenvolvimento Científico e Tecnológico do Maranhão - FAPEMA (PROCESS: CBIOMA-02946/12).

\section{References}

Almeida ACS, Silva LP, Jesus FG, Nogueira L, Sousa Neto M, Cunha PCR (2015) Efeito de indutores de resistência em híbridos de milho na atratividade do pulgão Rhopalosiphum maidis (Fitch, 1856) (Hemiptera: Aphididae). Rev agrarian. 8(27): 23-29.

Almeida VT, Ramos VM, Saqueti MB, Gorni PH, Pacheco AC, Leão RM (2017) Bioactivity of ethanolic extracts of Euphorbia pulcherrima on Spodoptera frugiperda (J.E. Smith) (Lepidoptera: Noctuidae). Afr J Biotechnol. 16(13): 615-622.

Alvarenga R, Moraes JC, Auad AM, Coelho M, Nascimento AM. Induction of resistance of corn plants to Spodoptera frugiperda (J.E. Smith, 1797) (Lepidoptera: Noctuidae) by application of silicon and gibberellic acid. Bull Entomol Res. 107(4): 527-533

Antunes CS, Moraes JC, Antônio A, Silva VF (2010) Influência da aplicação de silício na ocorrência de lagartas (Lepidoptera) e de seus inimigos naturais chaves em milho (Zea mays L.) e em girassol (Helianthus annuus L.). Biosci J. 26(4): 619-625.

Assis FA, Moraes JA, Assis GA, Parolin FJT (2015) Induction of caterpillar resistance in sunflower using silicon and acibenzolar-s-methyl. J Agr Sci Tech. 17(3): 543-550.

Barbosa AS (2007) Potencial de ação elicitora dos biofertilizantes líquidos na indução de resistência sistêmica vegetal. Rev Bras Agroecologia. 4(2): 1453-1457.

Boregas KGB, Mendes, SM, Waquil JM, Fernandes GW (2013) Estádio de adaptação de Spodoptera frugiperda (J. E. Smith) (Lepidoptera: Noctuidae) em hospedeiros alternativos. Bragantia. 72(1): 61-70.

Costa RR, Moraes JC, Antunes CS (2007). Resistência induzida em trigo ao pulgão Schizaphis graminum (Rondani, 1852) (Hemiptera: Aphididae) por silício e acibenzolar-s-methyl. Ciênc Agrotec. 31(2): 393397.

Costa RR, Moraes JC, Costa RR (2011) Feeding behaviour of the green bug Schizaphis graminum on wheat plants treated with imidacloprid and/or silicon. J Appl Entomol. 135(1): 115-120.

Cruz I, Turpin, FT (1982) Efeito da Spodoptera frugiperda em diferentes estágios de crescimento da cultura do milho. Pesq Agropec Bras. 17(3): 355-359.

Datnoff LE, Snyder GH, Korndorfer GH (2001) Silicon in agriculture, 1rd edn. Elsevier Science, Amsterdam.424

Freitas LM, Junqueira AMR, Michereff Filho M (2011) Potencial de uso do silício no manejo integrado da traçadas-cruciferas, Plutella xylostella, em plantas de repolho. Rev Caatinga. 25(1): 8-13.

Goussain MM, Moraes JC, Carvalho JG, Nogueira NL, Rossi ML (2002) Efeito da aplicação de silício em plantas de milho no desenvolvimento biológico da lagarta do cartucho Spodoptera frugiperda (J.E. Smith) (Lepidoptera Noctuidae). Neotrop Entomol. 31(2): 305-310.

Grenne GL, Lepla NC, Dickerson WA (1976) VelvetIran caterpillar: a rearing procedure and artificial medium. J Econ Entomol. 69(4): 487-488. 
Gulsen, O, Eickhoff, T, Heng-Moss T, Shearman R, Baxendale F, Sarath G (2010) Characterization of peroxidase changes in resistant and susceptible warm-season turfgrasses challenged by Blissus occiduus. Arthropod-Plant Inte. 4(1): 45-55.

Keeping MG, Kvedaras OI, Bruton, AG (2009) Epidermal silicon on sugarcane: cultivar differences and role in resistance to sugarcane borer Eldana saccharina. Environ Exp Bot. 60(1): 54-60.

Körndorfer AP, Grisoto E, Vendramim JD (2011) Induction of insect plant resistance to the spittlebug Mahanarva fimbriolata Stal (Hemiptera: Cercopidae) in sugarcane by silicon application. Neotrop Entomol. 40(3): 387-392.

Massey F, Hartley SE (2009) Physical defenses you down: progressive and irreversible impacts of silica on insect herbivores. J Anim Ecol. 78(1): 281-291.

Nascimento AM, Assis FA, Moraes JC, Salomura R (2014). Não preferência a Spodoptera frugiperda (Lepidoptera: Noctuidae) induzida em arroz pela aplicação de silício. Rev Bras Ciênc Agrar. 9(2): 215-218.

Nascimento AM, Assis FA, Moraes JC, Souza BHS (2018) Silicon application promotes rice growth and negatively affects development of Spodoptera frugiperda (J.E.Smith). J Appl Entomol.142: 241-249.

Pereira RRC, Moraes JC, Prado E, Costa RR (2010) Resistance inducing agents on the biology and probing behaviour of the greenbug in wheat. Sci Agric. 67(4): 430-434.

Rodriguez HC, Vendramim JD (1996) Toxicidad de extractos acuosos de Meliaceae em Spodoptera frugiperda (Lepidoptera: Noctuidae). Manejo Integr Plagas. 42: 14-22.
Silva AA, Alvarenga R, Moraes JC, Alcantra E (2014) Biologia de Spodoptera frugiperda (J. E. Smith) (Lepidoptera: Noctuidae) em algodoeiro de fibra colorida tratado com silício. EntomoBrasilis. 7(1): 65-68.

Silva FAZ, Azevedo CAV (2016) The Assistat Software Version 7.7 and its use in the analysis experimental data. Afr J Agric Res. 11(39): 3733-3740.

Stangarlin JR, Kuhn OJ, Toledo MV, Portz RL, Schwan-Strada KRF, Pascholati, SF (2011) A defesa vegetal contra fitopatógenos. Sci Agrar Paran. 10(1): 18-46.

Thomazoni D, Formentini, MA, Alves LFA (2014) Patogenicity of entomopathogenic fungi to Spodoptera frugiperda (Smith) (Lepidoptera: Noctuidae). Arq Inst Biol. 81(2): 126133.

Tomquelski GV, Martins GLM, Papa G (2007) Efeito dos indutores de resistência acibenzolar-s-metil e silício na biologia de Alabama argillacea (Lepidotera: Noctuidae) em algodoeiro. Rev Agric. 82(2): 170-175.

Toscano LC, Fernandes MA, Rota M, Maruyama WI, Andrade JV (2016) Híbridos de milho frente ao ataque de Spodoptera frugiperda em associação com adubação silicatada e o efeito sobre o predador Doru luteipes. Rev Agric Neotrop. 3(1): 51-55.

War AR, Paularj MG, Ignacimuthu S, Sharma HC (2015) Induced resistance to Helicoverpa armigera through exogenous application of jasmonic acid and salicylic acid in groundnut, Arachis hypogaea. Pest Manag Sci. 71(1): 72 82. 